\title{
People Are Primary: A Perspective from the Keystone IV Conference
}

\author{
Rebecca S. Etz, PhD
}

As a person invested in personal doctoring, what promises are you willing to make about when and where you will "be there" for others? Attendees of the G. Gayle Stephens Keystone IV Conference answered that question on submitted index cards and through ongoing conference discussions. Those data were analyzed using grounded theory and combined to develop the following answer in aggregate: We will be held accountable to those who need us. We understand the need for expertise and compassion as we help others to navigate the intersection of science and humanism. We will serve as leaders in personal, public, and political conversations. We will mark a path for the profession ensuring alignment of personal practices with professional principles. We will not allow the needed conversations of processes, data points, and determinations of value to undermine our relationships with our patients. We will be there for you. Attentive and fully present. We will care for you when you have no need and you do not ask. We will center that care in your lived experience of health and illness, knowing you over time. We will be here for you now, over time and across distance, in ways that foster the feeling of wholeness and belonging. We will use the best knowledge, best tailored to meet our shared understanding of your goals and aspirations. (J Am Board Fam Med 2016;29:S40-S44.)

Guest editors' note: This Article can be seen as the primary results Article from the G. Gayle Stephens Keystone IV Conference. It is an unusual Article in that it presents a rigorous assessment of the conference record by a careful observer of the conference, blended with relevant literature and intellectual synthesis of these "inputs" by its author. It formulates answers to the conference's question.

Keywords: Doctoring, Family Medicine, Family Physician, Health Care Delivery, Personal Physician, Population Health, Primary Care, Professionalism, Social Justice

"The doctor we have in mind... is looking after people as people and not as problems." -Fox, $1960^{1}$

"Family physicians are committed to fostering health and integrating health care for the whole person by

This article was externally peer reviewed.

Submitted 18 December 2015; revised 12 April 2016; accepted 18 April 2016.

From the Department of Family Medicine and Population Health, Virginia Commonwealth University School of Medicine, Richmond.

Funding: none.

Conflict of interest: none declared.

Corresponding author: Rebecca S. Etz, PhD, Department of Family Medicine and Population Health, Virginia Commonwealth University School of Medicine, One Capital Square Building, 830 East Main St, Rm 629, Richmond, VA 23298-0101 (E-mail: Rebecca.Etz@vcuhealth.org). bumanizing medicine and providing science-based, bigh-quality care." —Green et al, $2007^{2}$

"Family physicians are personal doctors for people of all ages and health conditions. . . . They are ideal leaders of bealth care systems and partners for public bealth." -Phillips et al, 2014

"To discover who people think they are, what they think they are doing, and to what end they think they are doing it, it is necessary to gain a working familiarity with the frames of meaning within which they enact their lives." -Geertz, $1984^{4}$

It was a difficult question, and it was answered by everyone who attended the Gayle G. Stephens Keystone IV Conference. Take a moment to consider your own answer. Stop right now and focus. As a person invested in personal doctoring, what 
promises are you willing to make about when and where you will "be there" for others? How will you hold yourself accountable? The purpose of this article is to discuss how those attending Keystone $\mathrm{IV}$ answered that same question.

For the past 10 years, I have engaged in what I would call "anthropology as intervention." I know of no other way to describe it. The work product we call "research" is only part of what I do. Each day at work, I am the ethnographer, participating and observing, apprenticing myself to those with whom I work, learning how they derive significance in their world and using that knowledge to help them, and me, solve social problems that matter. I work in a department of family medicine and population health. Our work is, by necessity and by design, collaborative. We shape and constrain the focus of our studies such that they are informed and enriched by the everyday realities of those with whom we toil. Anthropology, like personal doctoring, finds meaning in the everyday activities that occupy us. At work we search for ways to be continually inspired by what it is we are trying to do and, on occasion, we look to each other to remind ourselves of what that is.

Like anthropology, it is the imperative of personal doctors to learn both through doing and through telling stories about the things we have done. Such was the impetus for the Keystone IV Conference. Several past efforts have attempted to define, envision, redefine, and reimagine what personal doctoring is. And yet, when we consider those efforts and witness their change over time (1960 to 2014), the heart of the matter remains true: Personal doctors look after people as people, they invest health and medicine with a strong belief in the fullness and dignity of humanity, and they do so with conviction at both the personal and public level. Almost as consistent are the semipredictable intrusions of the medical industrial complex in which the world of personal doctoring resides. These are the times when social actions, like the Keystone IV Conference, are most necessary.

\section{Methods}

Discussed in this article are the main conceptual outcomes of Keystone IV as expressed within the promises made by conference participants. The data included in this analysis are varied: 58 promises written on $4 \times 6$ index cards, hallway conver- sations turned into data through jottings, scripted plenary sessions, and notes taken during the many facilitated group sessions. Keystone IV participants were equally diverse: clinicians purposefully sampled from a spectrum of disciplines; patient representatives; researchers from social science, policy, and health services. An iterative process was used to best evaluate and discuss the ways in which the organizing themes of this conference-place, time, and relationship-were reflected among participant promises. ${ }^{5}$ Data were captured, coded, read, and reread using a grounded theory approach to locate conceptual areas of agreement and of discord. The conclusions reached were then cross-checked by vetting them with conference attendees and the conference planning committee. Those consulted offered clarifications that were incorporated until consensus was reached that this report is an accurate representation of ideas present among the promises made. In the sections below I consider the implications of information shared in participant promises and nest that understanding within the historic context of the conference and of personal doctoring.

\section{Results}

\section{Doctors Agree: These Are Troubling Seas}

The comments, promises, and conversations shared among conference participants reflect the tidal changes that currently occupy the world of personal doctoring. Some areas of consensus are always easy to find. If there is one thing in 2015 on which personal doctors can agree, it is that they feel under fire, holding strong while also witnessing a certain amount of withering on the vine. It is as if they are bearing witness to the potential end of an era in which the people in medicine matter. Health systems designed around fiduciary responsibilities, competing interests organized around restrictive business models, and intrusions of technology intended to support but usurped by regulatory aims have created a quality chasm. This chasm is not one of processes and outcomes. It is between the business of medicine and the lived experience of the human condition. Medicine is dehumanizing and has become more so over time; personal doctoring is not. The personal is the relational, the contextual, and the meaningful over time. The promise of personal doctoring lies in the significance of that "personal" qualifier. It is that personal, relational 
quality in which the promise of healing abides and to which the vision of the profession attends.

The purpose and organizing principle of the Keystone IV Conference was to answer a simple question: What promises will personal physicians make publicly, and keep, in the evolving US health care system, in particular as to when and where they will "be there" for their patients?

Two and a half days of conversation focused on this question and the key elements contained within it: time (when), place (where), and relationship (be there). Those in the room struggled with the lived biographies they carried with them. The older generation wanted desperately to share stories of the way things once were. They felt an imperative to share with younger physicians the power and potential found in close and personal bonds with others, established over time and at moments critical and whimsical and raw with intensity. The younger generation respected nostalgia but worried about stalling momentum. They wanted to plow ahead and harness the power and potential found in political action and systemic disruption. And then there was the newest generation-those still formulating their questions and path and who arrived ready to be inspired, to participate, and to carry on the message.

Each Keystone generation brought with them their own ways of knowing. The author and philosopher Ken Wilber ${ }^{6}$ and Stange et $\mathrm{al}^{7}$ provide a conceptual framework that eases our ability to make structural sense of these different ways of knowing (see Figure 1). Wilber imagines 4 quadrants governed by 2 complementary vectors. One vector relates to how we experience the world and

Figure 1. Wilber ways of knowing overlaid with conference themes.

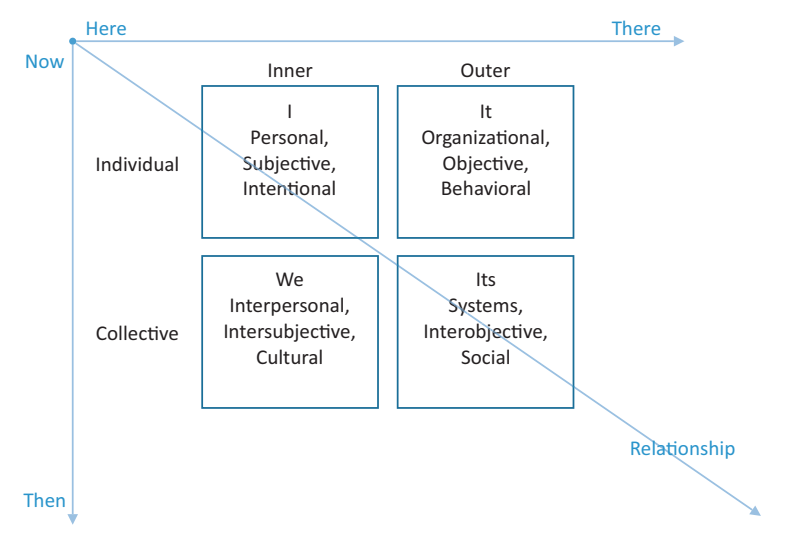

whether this experience is subjectively based (inner) or objectively based (outer). The second vector accounts for whether the knowledge or experience in question was generated 1 on 1 (individual) or as part of a group (collective). The conference themes of place, time, and relationship are easily overlaid on this conceptual framework in ways reminiscent of the work done by Fabian ${ }^{8}$ to examine connections between time and being known. When the "when" and "where" of personal doctoring is "here" and "now," it is best represented in the subjective, 1-on-1 experience of health seeking and healing that so epitomizes care delivery. Yet all disciplines invested in personal doctoring hold areas at stake beyond the clinical encounter. As we move along the spectrums of time and place, ways of knowing and the relationships in which we invest become more abstract, group oriented, systemic, and external.

The quadrants described by Wilber ${ }^{6}$ are useful for understanding the variation that existed among the written promises turned in at the end of the Keystone Conference (see Figure 2). His framework helps us to understand the implications of collective and subjective ways of knowing for the social actions they inspire. It helps us to understand that there is no conflict between the being of personal doctors and the doing of doctoring. Incumbent within the promises made is a willingness to assume a way of moving through the world that is consistent with the principles that guide personal doctoring as a profession. Keystone IV attendees agreed that they would pledge action consistent with their principles, recognizing as other social movements have that the personal, professional,

Figure 2. Promises as understood through Wilber ways of knowing.

\begin{tabular}{|c|c|c|}
\hline & Inner & Outer \\
\hline Individual & $\begin{array}{l}\text { Trust, balance, touch, } \\
\text { presence, personalization, } \\
\text { personal knowledge over } \\
\text { time, sense-making, } \\
\text { comprehensiveness, } \\
\text { rootedness, here and now, } \\
\text { over time, and across } \\
\text { distance }\end{array}$ & $\begin{array}{l}\text { Competent and } \\
\text { replenished workforce, } \\
\text { evidence-based practice, } \\
\text { practice-based evidence, } \\
\text { generational mentored } \\
\text { learning, be there now as } \\
\text { stewards of the discipline }\end{array}$ \\
\hline Collective & $\begin{array}{l}\text { Mission-driven work, } \\
\text { advocacy for patients, } \\
\text { care tailored to patient } \\
\text { populations, access, social } \\
\text { justice, attention to social } \\
\text { determinants of health, be } \\
\text { present when most } \\
\text { needed, professionalism }\end{array}$ & $\begin{array}{l}\text { New models of care, } \\
\text { payment reform, evidence- } \\
\text { based guidelines, } \\
\text { measures, build societal } \\
\text { trust, build public } \\
\text { authority for personal } \\
\text { doctoring, be there when } \\
\text { most needed }\end{array}$ \\
\hline
\end{tabular}


and political are interdependent in any humanist endeavor.

Wilber's ${ }^{6}$ model also helps us to discover similarities in the face of difference. There was clearly tension in the room among versions of personal doctoring as lived experience, as publicly negotiated, and as enacted through policy—each with its own implied social contract of stakeholder assumption and expectation. Yet to be at Keystone IV was to realize that each participant, regardless of expectation, was rediscovering his or her vision of personal doctoring with the promise of carrying that vision forward. And within that discovery, the promise itself is the most important point, and that point is simple: We will be held accountable to those who need us.

\section{Generational Mentoring: Charting the Right Course}

Gayle Stephens taught a generation of personal doctors to hold their patients in a state of grace. He was 1 of many to disrupt common misunderstandings of how health is won and lost. To locate primary care practices in the context of where people live, work, and play was not counterculture because it went against the grain; it was counter because it ruptured thought. It located health and healing in communities, in people, and in relationships. He defined personal doctoring as a profession in which healers understood the need for expertise and compassion as they helped others navigate the intersection of science and humanism. Few things are as important to a newly forming field, or aspiring young practitioners, as finding the right mentor, developing that vision, or charting that course.

The promise of the Keystone IV Conference was a reconnection with that emotional and intellectual lineage. I was surprised to learn how many people at the conference had yet to discover Gayle's legacy. It reminded me of Alice Walker's essay, "Looking for Zora." In it, Walker describes her quest to find and mark the unmarked grave of Zora Neale Hurston. Before Walker won a Pulitzer Prize, she was Alice the graduate student and the black woman writer in search of a mentor and muse. She had been looking for work that granted both her, and the people about whom she wrote, the dignity to which they were entitled. Although Zora Neale Hurston now holds a place central to the canons of literature and critical social theory, at the time of Walker's search she was unknown.
Learning more about her life, Alice found that Hurston, a foundational force during the Harlem Renaissance, died of malnutrition, in poverty, and was buried in an unmarked grave. "Looking for Zora" is as much a statement about the importance of finding community, history, and belonging as it is about looking for a lost grave.

One of my favorite moments in the essay is when Alice walks out into the middle of an overgrown field. Local records said Hurston's grave could be found somewhere in an acre of thicket, and Alice, with the help of Rosalee from the mortuary, waded in.

“Zora!” Alice yells, as loud as she can ... "Are you out here?"

"If she is," grumbles Rosalee, "I hope she'll keep it to herself . . . or I am gone."

It is both funny and deeply meaningful. We are there, with Alice, in that moment. We understand her determination and courage, breaking a new path in ground that is known to be hostile. And when she finds Hurston's grave, she marks it so that the path, and the influence, will be easier for others to find. Many at Keystone IV traveled as Alice did, in search of connection and intellectual kinship. The unfortunate state of personal doctoring leaves far too many with the feeling of standing alone, exposed, in the middle of a field, with no footsteps to follow, wondering if it was even prudent to enter.

Attendees at Keystone IV promised a path and a way forward. Recognizing that their vision on arrival was muddy, the promises made at the conference were not simply in the words of "being there, when and where" they are needed, but also in their willingness to reexamine the alignment of their personal practices with their professional principles. The biggest threat to personal doctoring is the co-opting of the profession by the distracting conversations of technology, business, and auditing. In his pivotal essay on family medicine as counterculture in 1979 , Stephens ${ }^{10}$ spoke to this point directly: "Medicine has not noticed that the tides of its intellectual fortune have gone out. ... We are grounded on a shoal and we are alone, because in the euphoria of our halcyon days we are guilty of overweening pride-what the theologians call $b u$ bris."

If there was a weakness at the conference, it was in the lack of critical reflection on this key element. The urge to protect the profession, to defend newly 
won "bobbles of prestige,"11 and to stave off those structural forces perceived as a threat has become a damaging distraction. By allowing everyday actions to become so keenly focused as counter to opposing forces, the field of personal doctoring acts on the ways of knowing of others, rather than on its own. It becomes complicit in the very dehumanizing dynamics that personal doctoring seeks to avoid and is in danger of embodying the hubris against which Stephens ${ }^{10}$ warned. Keystone IV attendees seemed to be invested in the hard choice of leaving that hubris behind. The promises made by each attendee, and submitted at the conference's end, share a common theme: We will be held accountable. We will return to our roots. Our language and actions have become overladen with thoughts of constraints, processes, data points, and determination of value. We have allowed it to invade our practice and in doing so have broken 1 of our most basic principles - that above all else, we will be there, when and where. That we, and not those who seek our help, will be responsible for navigating the obstacles that stand between.

\section{Steering Clear of the Shoals}

"[Personal doctors] have glimpsed a new vision of what medical care can and ought to be-and we have turned toward it, but as every mountain climber knows, the big ones have false summits which must be passed to scale the real top." - Gayle Stephens, $1979^{10}$

Navigate anywhere and you will encounter your fair share of troubling currents and shallows. Still, a generalized message or direction is clear. There is no single promise. Yet living on the surface and throughout the health care system the promise of personal doctoring is apparent and was described by Keystone participants:

I will be there for you. Attentive and fully present. I will care for you when you have no need and you do not ask. I will center that care in your lived experience of health and illness, knowing you over time. I will be here for you now, over time and across distance, in ways that foster the feeling of wholeness and belonging. I will provide centered care, personal care, expert care, and experiential care, despite economic, technological, and political distractions that threaten to enter the healing place we create together. Because I know you, I will be able to use the best knowl- edge, best tailored to meet our shared understanding of your goals and aspirations.

It is mission driven, drawing on the ideals foundational and formative of family medicine and general practice before it. It reflects a deeply held belief in the value of personal connection, of being known, of unfettered access and trust. It reflects the imperative of personal doctoring to support personal goals of health and population-based goals of prevention as represented in people, across communities, and throughout life spans. As a generalized promise, it both reveals troubles and remains hopeful.

The author deeply appreciates conversations with Keystone IV attendees who offered feedback during the writing process: Kurt Stange, David Loxterkamp, Lauren Hughes, Paul James, Linda Niebauer, and Larry Green. Equally important was the intellectual community and writing suggestions offered by some who did not attend the conference: Anton Kuzel, Lindsey McGuire, Marshall Brooks, and Martha Gonzalez. This article was conceived and supported by valuable consultation with the conference planning committee: Frederick Chen, Jack Colwill, Jennifer DeVoe, Tricia Elliott, John Frey, Robert Graham, Larry Green, and Lauren Hughes.

\section{References}

1. Fox TF. The personal doctor and his relation to the hospital. Lancet 1960;1:743-60.

2. Green LA, Pugno P, Fetter G, Jones SM. Preparing the Personal Physician for Practice (P4): A national program testing innovations in family medicine residencies. J Am Board Fam Med 2007;20:329-31.

3. Phillips RL, Brungardt S, Lesko SE, et al. The future role of the family physician in the United States: a rigorous exercise in definition. Ann Fam Med 2014;12: 250-5.

4. Geertz C. Distinguished lecture: anti anti-relativism. Am Anthropol 1984;86:263-78.

5. Borkan, J. Immersion/crystallization. In: Crabtree BF, Miller WL, editors. Doing qualitative research. 2nd ed. Thousand Oaks, CA: Sage Publications; 1999. 179-94.

6. Wilber K. Sex, ecology, spirituality: the spirit of evolution. Boston, MA: Shambhala; 1995.

7. Stange KC, Miller WL, McWhinney I. Developing the knowledge base of family practice. Fam Med 2001;33:286-97.

8. Fabian J. Time and the other: how anthropology makes its objects. New York: Columbia University Press; 1983.

9. Walker A. Looking for Zora. In Search of Our Mothers' Gardens: Womanist Prose. New York: Harvest Books; 1983. p. 93-118.

10. Stephens G. Family medicine as counterculture. Fam Med 1989;21:103-9.

11. Stange KC. Keystone IV paper. J Am Board Fam Med 2015. 